\title{
Development of a Real-Time RT-PCR SYBR Green Assay for Tomato ring spot virus in Grape
}

\author{
Elwin L. Stewart, Xinshun Qu, Barrie E. Overton, Fred E. Gildow, and Nancy G. Wenner, Department of Plant \\ Pathology, The Pennsylvania State University, University Park 16802; and Deborah S. Grove, Huck Institute, War- \\ tik Laboratory, The Pennsylvania State University
}

\begin{abstract}
Stewart, E. L., Qu, X. S., Overton, B. E., Gildow, F. E., Wenner, N. G., and Grove, D. S. 2007. Development of a real-time RT-PCR SYBR Green assay for Tomato ring spot virus in grape. Plant Dis. 91:1083-1088.

Grapevines infected with Tomato ring spot virus (ToRSV) pose an economic risk for growers in the northeastern United States. This study describes a one-step real-time reverse-transcription polymerase chain reaction (RT-PCR) SYBR Green assay for detecting ToRSV in grapevines. Two newly designed primer pairs based on the ToRSV coat protein gene sequence were evaluated for specificity and optimized for a SYBR Green assay. The primer pair ToRSV1f/1r yielded a 130-bp product with strong primer-dimer products, whereas the primer pair ToRSV2f/2r yielded a 330-bp product with weak primer dimer products. Real-time RT-PCR detected ToRSV in more naturally infected grapevines maintained in the greenhouse than did enzyme-linked immunosorbent assay. The nucleotide sequences of the fragments amplified from grapevine growing in Pennsylvania using real-time PCR were divergent from previously published sequences.
\end{abstract}

Additional keywords: Grape yellow vein virus, Vitis vinifera

Tomato ring spot virus (ToRSV) is a polyhedral nematode-transmissible virus, endemic to North America and causes disease symptoms in many economically important crops, including grape (15). In a survey of declining grapevines in Pennsylvania and New York vineyards, ToRSV was detected by enzyme-linked immunosorbent assay (ELISA) in 5 out of 21 Native American, 30 out of 81 interspecific hybrid, and 11 out of 61 Vinifera cultivar blocks (16). Infected vines often decline and produce short shoots with shortened internodes, smaller mottled leaves, and clusters with fewer berries of uneven size. Infection with ToRSV in grape in the northeastern United States reduces yields of high-quality juice for wine and necessitates premature replacement of vines. Several weed species commonly found in vineyards, such as dandelion (Taraxacum officinale Weber), sheep sorrel (Rumex acetosella L.), common chickweed (Stellaria media L.), red clover (Trifolium pre-

Corresponding author: E. L. Stewart

E-mail: els4@psu.edu

Accepted for publication 11 April 2007.

doi:10.1094/PDIS-91-9-1083

(C) 2007 The American Phytopathological Society tense L.), and narrow-leaf plantain (Plantago lanceolata L.), serve as hosts for the virus (12). Mountain et al. (11) reported that dandelion plants infected with ToRSV produced seed that were capable of disseminating the virus. Nematodes (Xiphinema spp.) feeding on infected grapevines can transmit to other grapevines. ToRSV also can be spread by mechanical inoculation (6) and planting of infected nursery stock.

ToRSV isolates can differ from each other in the symptoms expressed on indicator plants, and the severity of disease induced by different isolates of ToRSV may vary according to geographic locations (1). Multiple strains of ToRSV from different serogroups can infect grape (1,6,18). Gooding (6) described Grape yellow vein virus (GYV) in Vitis vinifera L. cv. Carignane from California. He demonstrated complete symptom expression 2 to 3 years after grapevines were inoculated with sap from yellow vein-diseased vines and with purified virus. Gooding (6) showed that GYV was related to ToRSV. Bitterlin and Gonsalves (1) placed GYV in serogroup B and showed that GYV produced moderate symptoms when inoculated on Nicotiana benthamiana Domin., whereas another ToRSV isolate obtained from grape in Canada belonging to serogroup $\mathrm{E}$ showed severe symptoms on $N$. benthamiana. Wang and Sanfaçon (18) showed that GYV from grape shared 78 to $81 \%$ sequence similarity with isolates obtained from raspberry and peach and provided the first molecular data suggesting that GYV is a unique strain that differs from ToRSV strains from other hosts.

Reverse-transcription (RT) polymerase chain reaction (PCR) is widely used as a diagnostic tool in virus research (7-9). Pham et al. (13) reported that SYBR Green real-time PCR detection of the Newcastle virus was 100 times more sensitive than conventional PCR. Real-time RT-PCR using SYBR Green to detect ToRSV would provide a rapid and highly sensitive method for indexing grape nursery stock, and the sequences that can be generated from the real-time RT-PCR products could be used to show variation in virus strains. Two conventional RT-PCR assays have been published for the detection of ToRSV $(7,10)$. The PCR products reported $(7,10)$ are larger, 449 and $668 \mathrm{bp}$, respectively, than those recommended for a SYBR Green assay which, under optimal conditions, should be 100 to $300 \mathrm{bp}$ in length. Primers for immunocapture (IC)-PCR were developed by Rowhani et al. (14) for the detection of ToRSV, but were reported to yield multiple PCR products from infected plant tissues as well as a PCR product from noninfected cucumber. Multiple PCR products interfere with accurate detection of the target pathogen because a SYBR Green assay generates a fluorescent signal for each product; consequently, the Rowhani et al. (14) primers cannot be directly adapted to a SYBR Green assay.

The presence of PCR inhibitors can negatively affect PCR efficiency and decrease the sensitivity of real-time RT-PCR $(3,19)$. Tattersall et al. (17) evaluated 15 different methods for RNA extraction from grapevine, showing that either lithium chloride precipitation or the RNeasy kit from Qiagen with the addition of 3.3\% (wt/vol) polyethylene glycol (PEG) per milliliter of extraction buffer yielded highquality RNA with reduced protein contamination. This article describes a onestep real-time RT-PCR assay for the detection of ToRSV in grapevine and demonstrates the influence of the RNeasy extrac- 
tion with and without PEG on PCR efficiency in the SYBR Green assay.

\section{MATERIALS AND METHODS}

Plant materials. Symptomatic vines of grape cvs. Vidal Blanc and DeChanauc collected from commercial vineyards and Chenopodium quinoa Willd. inoculated with ToRSV originally isolated from apple served as the assay material in this study (Table 1). Five replicates of nine hotwater-treated $\left(50^{\circ} \mathrm{C}\right.$ for $\left.30 \mathrm{~min}\right)$ cultivars also were tested for the presence of ToRSV (Table 1). Hot-water treatment was used to reduce the numbers of external and internal pests and pathogens in dormant cuttings $(2,4)$.

Design of real-time PCR primers. Coat protein gene sequences were obtained from GenBank for the following virus isolates: GYV (AF135411), Peach yellow bud mosaic virus (PYBMV, AF135412), ToRSV from raspberry (RASP, AF135413), and T392 (unknown host, AF135414). Two different primer pairs were designed based on conserved regions of the coat protein found in GenBank sequences: pair 1, forward primer, ToRSV1f (5'-TACCAATTC ATGTGTTATTTCG-3'), reverse primer, ToRSV1r (5'-ACTCAAACCTCCAGTCA TCG-3') for the amplification of a 130-bp PCR product; and pair 2, forward primer, ToRSV2f (5'-GACTGGAGGTTTGAGT GGC-3'), reverse primer, ToRSV2r (5'CTCACGTAAATGTATGGTTCC- $3^{\prime}$ ) for the amplification of a 330-bp PCR product. The software program MacMolly TetraLite (the freeware version of Soft Gene's MacMolly Tetra software package) was used to determine the propensity of primers to form dimers and calculate optimal annealing temperatures. Primers were tested for specificity using blast searches in GenBank and by attempting to amplify nontarget RNA extracted from a sample of
Peach rosette mosaic virus (PRMV; CPVC-0179) obtained from the Agriculture and Agri-Food Canada, Pacific AgriFood Research Centre.

ELISA detection of ToRSV from naturally infected samples. ELISA testing was conducted using the ToRSV ELISA system from Agdia (Elkhart, IN) following the manufacturers' instructions. Eighteen two- to three-bud cuttings were sampled randomly from symptomatic Vidal Blanc growing in two commercial vineyards in Pennsylvania. They all tested positive for ToRSV based on ELISA. The cuttings were rooted in bottom-heated wooden boxes in the greenhouse. Rooted cuttings were transplanted into $10-\mathrm{cm}$ pots containing a Farfard no. 4 potting mix. ELISA testing was conducted on roots and leaf tissues from 6-month-old rooted vines. ELISA results were compared with those obtained from the RT-PCR assay described below using the RNeasy extraction kit (Qiagen, Valencia, CA), without modification, over a subsequent 2-year period.

RNA extraction. In all, 80 to $100 \mathrm{mg}$ of fresh leaf tissue was ground in liquid nitrogen. RNA was extracted using the RNeasy Plant Mini Kit (Qiagen) following the manufacturer's instructions. The concentration of total RNA (plant + virus) was determined using a Nanodrop UV-Vis Spectrophotometer (ND-1000; Wilmington, DE).

RT-PCR assay for detection of ToRSV. For a single reaction, $11.75 \mu \mathrm{l}$ of a $1: 13$, $1: 25,1: 50$, or $1: 100$ dilution of RNA extract was added to the following: $12.5 \mu \mathrm{l}$ of QuantiTect SYBR Green reaction mix, $0.25 \mu \mathrm{l}$ of QuantiTect RT Mix (Qiagen), and $0.25 \mu \mathrm{l}$ of each primer from a $100-\mu \mathrm{M}$ stock solution ( $1 \mu \mathrm{M}$ final concentration), for a total reaction volume of $25 \mu \mathrm{l}$. All real-time RT-PCR amplifications were performed in a Cepheid Smart Cycler (Ce- pheid, Sunnyvale, CA) according to the manufacturer's instructions. Samples tested using the primer pair ToRSV1f/1r, were run as follows: $50^{\circ} \mathrm{C}$ for $30 \mathrm{~min}$ (reverse transcription), then $95^{\circ} \mathrm{C}$ for $15 \mathrm{~min}$ (hot start and inactivation of reverse transcriptase), followed by 40 cycles of $94^{\circ} \mathrm{C}$ for $25 \mathrm{~s}, 58^{\circ} \mathrm{C}$ for $30 \mathrm{~s}$, and $72^{\circ} \mathrm{C}$ for $30 \mathrm{~s}$ (optics on). Samples using the primer pair ToRSV2f/2r, were run as follows: $50^{\circ} \mathrm{C}$ for $30 \mathrm{~min}$, then $95^{\circ} \mathrm{C}$ for $15 \mathrm{~min}$, followed by 40 cycles of $94^{\circ} \mathrm{C}$ for $25 \mathrm{~s}, 55^{\circ} \mathrm{C}$ for $30 \mathrm{~s}$, and $72^{\circ} \mathrm{C}$ for $30 \mathrm{~s}$ (optics on). Melting curve analyses, or plots of fluorescence versus temperature, were used to identify melting temperature $\left(\mathrm{T}_{\mathrm{m}}\right)$ of amplified products using Cepheid software.

RNA extraction methods and PCR efficiency. The RNeasy extraction method from Qiagen, without modification, was compared with the RNeasy extraction method with the addition of $3.3 \%$ (wt/vol) PEG (Sigma-Aldrich, Germany) per milliliter of buffer RLT (Qiagen) following Tattersall et al. (17). Vidal Blanc grape leaf and petiole tissue $(100 \mathrm{ml})$ was ground in liquid nitrogen and added to $450 \mathrm{ml}$ of buffer RLT with and without PEG. The concentration of total RNA (plant + virus) was determined using a Nanodrop UV-Vis Spectrophotometer (ND-1000) for each extraction. RNA preparations were diluted $1: 10,1: 25,1: 50,1: 100,1: 500$, and 1:1000 and $11.75 \mu \mathrm{l}$ of each dilution was used in real-time reaction as previously described. The primer pair ToRSV2f/2r was selected for the real-time RT-PCR assay and PCR efficiency was determined using a calibration dilution curve and slope calculation by the equation $\mathrm{E}=10^{(-1 / \text { slope })}$, with $\mathrm{E}=2$ (indicating $100 \%$ efficiency). The threshold setting was 30 fluorescent units and used for determining the crossing points (cycle threshold $[\mathrm{Ct}]$ values) for the slope calculation. A $t$ test was used to evaluate

Table 1. Real-time reverse-transcription polymerase chain reaction (RT-PCR) results for the detection of Tomato ring spot virus in symptomatic and asymptomatic plant samples

\begin{tabular}{llccc}
\hline Plants & \multicolumn{1}{c}{ Origin } & Collection date & Symptoms & Real-time PCR Ct value $^{\mathbf{a}}$ \\
\hline Vidal Blanc & Brookmere Farm Vineyard, PA & 2005 & Symptomatic & 28.37 \\
Vidal Blanc & Mt. Nittany Vineyard and Winery, PA & 2005 & Symptomatic & 27.18 \\
Vidal Blanc & Mt. Nittany Vineyard and Winery, PA & 2005 & Symptomatic & 30.72 \\
Vidal Blanc & Mt. Nittany Vineyard and Winery, PA & 2005 & Symptomatic & 32.46 \\
Vidal Blanc & Mt. Nittany Vineyard and Winery, PA & 2005 & Symptomatic & 34.43 \\
DeChanauc & Mt. Nittany Vineyard and Winery, PA & 2005 & Symptomatic & 19.28 \\
DeChanauc & Mt. Nittany Vineyard and Winery, PA & 2005 & Symptomatic & 19.68 \\
DeChanauc & Mt. Nittany Vineyard and Winery, PA & 2005 & Symptomatic & 19.12 \\
DeChanauc & Mt. Nittany Vineyard and Winery, PA & 2005 & Symptomatic & 19.63 \\
Chenopodium quinoa Willd. & PA Department of Agriculture & 2006 & Symptomatic & 3.46 \\
C. quinoa Willd. & PA Department of Agriculture & 2006 & Symptomatic & \\
Hot-water treated & & & & 30.13 \\
Cabernet sauvignon & Steve Wright Vineyard, PA & 2005 & Asymptomatic & Asymptomatic \\
Cayuga & Foundation Plant Service (FPS), CA & 2006 & Asymptomatic & ND \\
Chambourcin & Happy Valley Vineyard, PA & 2005 & Asymptomatic & ND \\
Chancellor & Happy Valley Vineyard, PA & 2005 & Asymptomatic & ND \\
Chardonnay & Slate Quarry Winery, PA & 2005 & Asymptomatic & ND \\
Lemberger & Foundation Plant Service (FPS), CA & 2006 & Asymptomatic & ND \\
Traminette & Foundation Plant Service (FPS), CA & 2006 & Asymptomatic & ND \\
Root stock 3309C & Fruit Research and Extension Center, PA & 2005 & Asymptomatic & \\
Root stock SO4 & Lake Erie Research and Extension Center, PA & 2005 & & \\
\hline
\end{tabular}

${ }^{\text {a }} \mathrm{Ct}=$ cycle threshold and $\mathrm{ND}=$ not detected. 
difference among slope parameters estimated for each treatments (5).

Sequencing RT-PCR products. Following RT-PCR, $12 \mu \mathrm{l}$ of each selected
PCR product was separated on a $1 \%$ lowmelting agarose gel prepared in $1 \times$ Trisborate ethylenediamine tetraacetic acid buffer. PCR fragments were removed using
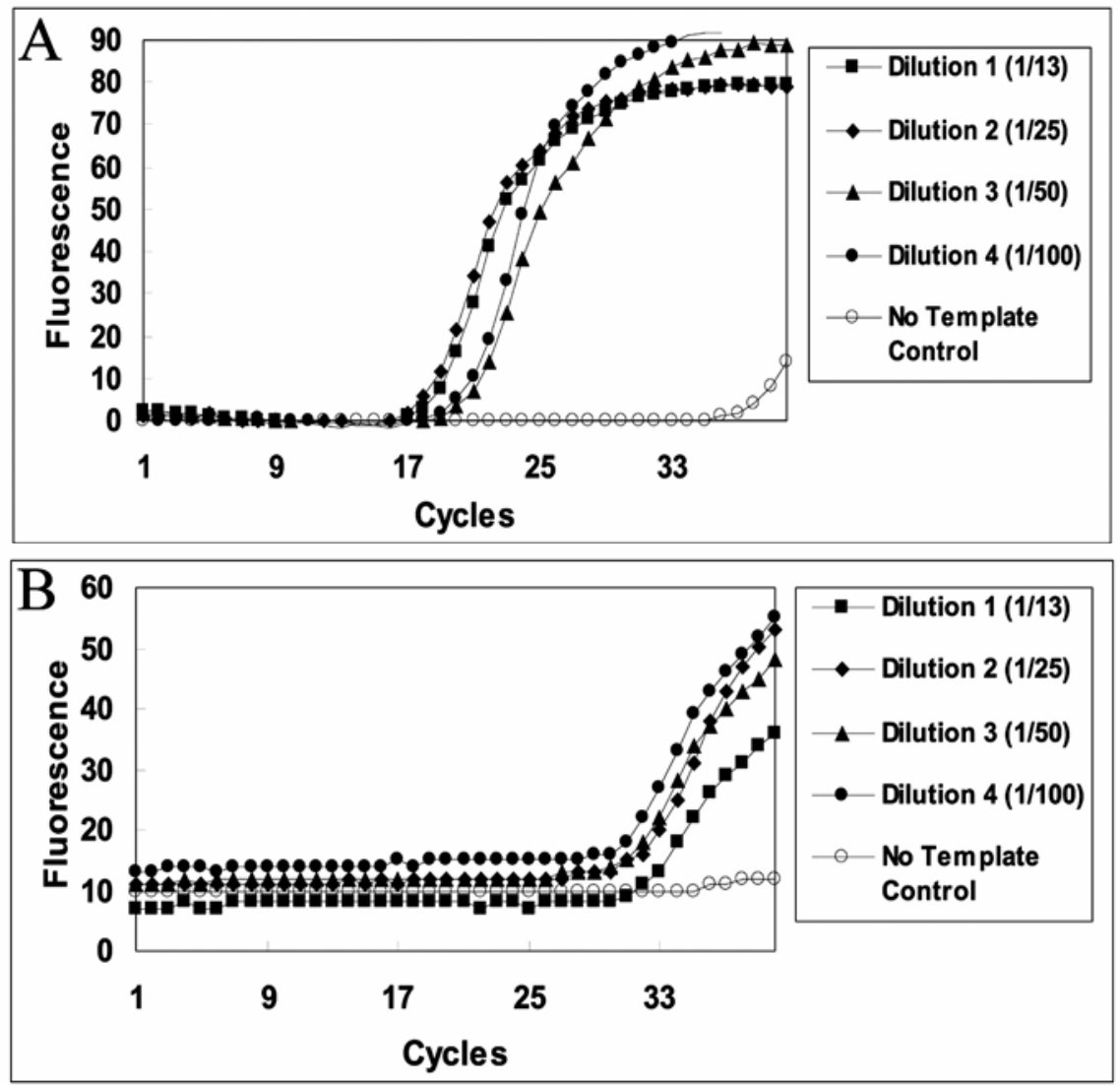

Fig. 1. Real-time polymerase chain reaction amplification profile for representative dilution series of RNA extracted from Tomato ring spot virus (ToRSV)-infected grapevine leaf tissue. A, Primer pair ToRSV 2f/2r. B, Primer pair ToRSV 1f/1r.

a sterile scalpel and purified using a QIAquick gel extraction kit (Qiagen) following the manufacturer's instructions. The ABI Prism Big Dye Terminator Cycle Sequencing Ready Reaction Kit (v.3.1; Applied Biosystems, Foster City, CA) was utilized for bidirectional sequencing of the PCR products. Performa DTR gel filtration cartridges from Edge Biosystems (Gaithersburg, MD) were used for purifying cycle sequencing products. Cycle sequencing products were separated on an ABI3100 Genetic Analyzer (Huck Institute, Penn State, University Park) and analyzed with $A B I$ sequencing software (v. 5.1.1).

Phylogenetic analysis. DNA sequences from the 330-bp products were trimmed at the $5^{\prime}$ and $3^{\prime}$ ends, assembled using SeqMan II option, then aligned in Clustal W using DNA Star (DNA Star Inc., Madison, WI). DNA sequence data from GenBank accessions were trimmed to match sequences generated in this study, and alignments were manually adjusted in PAUP* 4.0b8 (Sinaur Associates, Sunderland, MA). A phylogenetic analysis was performed using PAUP*. A maximum parsimony (MP) analysis was completed using the heuristic search option with starting trees obtained via random addition sequence (500 replicates) and Tree Bisection Reconnection (TBR) branch swapping. Gaps were treated as missing. Bootstrap analysis was performed in 500 replicates with random sequence addition (500 replicates). GenBank accession numbers for Pennsylvania PSU1 (Brookmere Farm Vineyard, PA) and ToRSV5 (Mt. Nittany Vineyard and Winery, PA) are DQ676503 and DQ676504, respectively.

Table 2. Comparison of enzyme-linked immunosorbent assay (ELISA) and reverse-transcription polymerase chain reaction (RT-PCR) results for the detection of Tomato ring spot virus from naturally infected rooted grapevine cuttings grown in the greenhouse ${ }^{\mathrm{a}}$

\begin{tabular}{|c|c|c|c|c|c|c|c|}
\hline \multirow[b]{3}{*}{ Cuttings } & \multicolumn{4}{|c|}{2004} & \multicolumn{3}{|c|}{2005} \\
\hline & \multirow[b]{2}{*}{ Symptoms $^{\mathrm{c}}$} & \multicolumn{2}{|c|}{ ELISA $^{b}$} & \multirow[b]{2}{*}{ RT-PCR (leaves) ${ }^{d}$} & \multirow[b]{2}{*}{ Symptoms $^{\mathrm{c}}$} & \multirow{2}{*}{$\begin{array}{c}\text { ELISA }^{\text {b }} \\
\text { Leaves }\end{array}$} & \multirow[b]{2}{*}{ RT-PCR (leaves) ${ }^{d}$} \\
\hline & & Leaves & Roots & & & & \\
\hline 1 & NA & - & + & Plant died & NA & NA & NA \\
\hline 2 & $\mathrm{~N}$ & - & - & - & $\mathrm{N}$ & - & - \\
\hline 3 & $\mathrm{~S}$ & - & + & + & $\mathrm{S}$ & + & + \\
\hline 4 & $\mathrm{~N}$ & - & - & - & NA & Plant died & NA \\
\hline 5 & $\mathrm{~S}$ & - & + & + & $\mathrm{S}$ & + & + \\
\hline 6 & $\mathrm{~N}$ & - & - & - & $\mathrm{N}$ & - & - \\
\hline 7 & $\mathrm{~S}$ & - & + & + & $\mathrm{S}$ & + & + \\
\hline 8 & $\mathrm{~S}$ & - & + & + & $\mathrm{S}$ & + & + \\
\hline 9 & $\mathrm{~N}$ & - & - & - & $\mathrm{N}$ & - & - \\
\hline $10^{\mathrm{e}}$ & M & - & - & - & M & - & + \\
\hline 11 & $\mathrm{~S}$ & - & + & + & $\mathrm{S}$ & + & + \\
\hline 12 & $\mathrm{~N}$ & - & - & - & $\mathrm{N}$ & - & - \\
\hline 13 & $\mathrm{~N}$ & - & - & - & $\mathrm{N}$ & - & - \\
\hline 14 & $\mathrm{~N}$ & - & - & - & $\mathrm{N}$ & - & - \\
\hline 15 & $\mathrm{~N}$ & - & - & - & $\mathrm{N}$ & - & - \\
\hline 16 & M & - & - & + & $\mathrm{S}$ & + & + \\
\hline 17 & $\mathrm{~N}$ & - & - & - & $\mathrm{N}$ & - & - \\
\hline 18 & $\mathrm{~N}$ & - & - & - & NA & Plant died & NA \\
\hline
\end{tabular}

a Vidal Blanc cuttings were used.

${ }^{\mathrm{b}}$ Results: $-=$ negative and $+=$ positive.

${ }^{c} \mathrm{NA}=$ not available; $\mathrm{N}=$ none; $\mathrm{M}=$ minor; $\mathrm{S}=$ severe

${ }^{\mathrm{d}}$ Results: $-=$ not detected and $+=$ detected with valid cycle threshold value.

e Cutting exhibited stunted growth but no other symptoms. 


\section{RESULTS}

ToRSV-specific primers. The sequences of primers ToRSV1f/1r and ToRSV2f/2r were compared with sequences in GenBank using BLAST search and no similarity to other organisms was found. When tested against RNA from an isolate of PRMV, a nontarget nepovirus, and healthy grapevine tissues, neither primer pairs (ToRSV1f/1r or ToRSV2f/2r) amplified a product. These results indicated that the primer pairs were specific for ToRSV. When tested against RNA from cutting 5, which was ELISA positive for ToRSV, the primer pair ToRSV2f/2r amplified a 330-bp PCR product with a weak PCR amplification at 37 cycles, which primer-dimer band occurring late in the were confirmed by melting curve analysis

and agarose gel observation (date not shown). The first derivative of the melting curve of the 330 -bp product was $82.0 \pm$ 0.12 and 75.5 for the primer-dimer. The amplification curves of the 330-bp product crossed the cycle threshold after 20 cycles (Fig. 1A). Cycle differences between twofold dilutions were not equal to one cycle as expected, suggesting the presence of PCR inhibitors. The primer pair ToRSV1f/ 1r amplified a single 130-bp PCR product with a strong primer-dimer band occurring late in the PCR amplification at 37 cycles. The first derivative of the melting curve of 130-bp product was $78.6 \pm 0.13$ and 70.7 for the primer-dimers. The amplification curves of the 130-bp product generally crossed the cycle threshold after 33 cycles (Fig. 1B). Cycle differences between two-
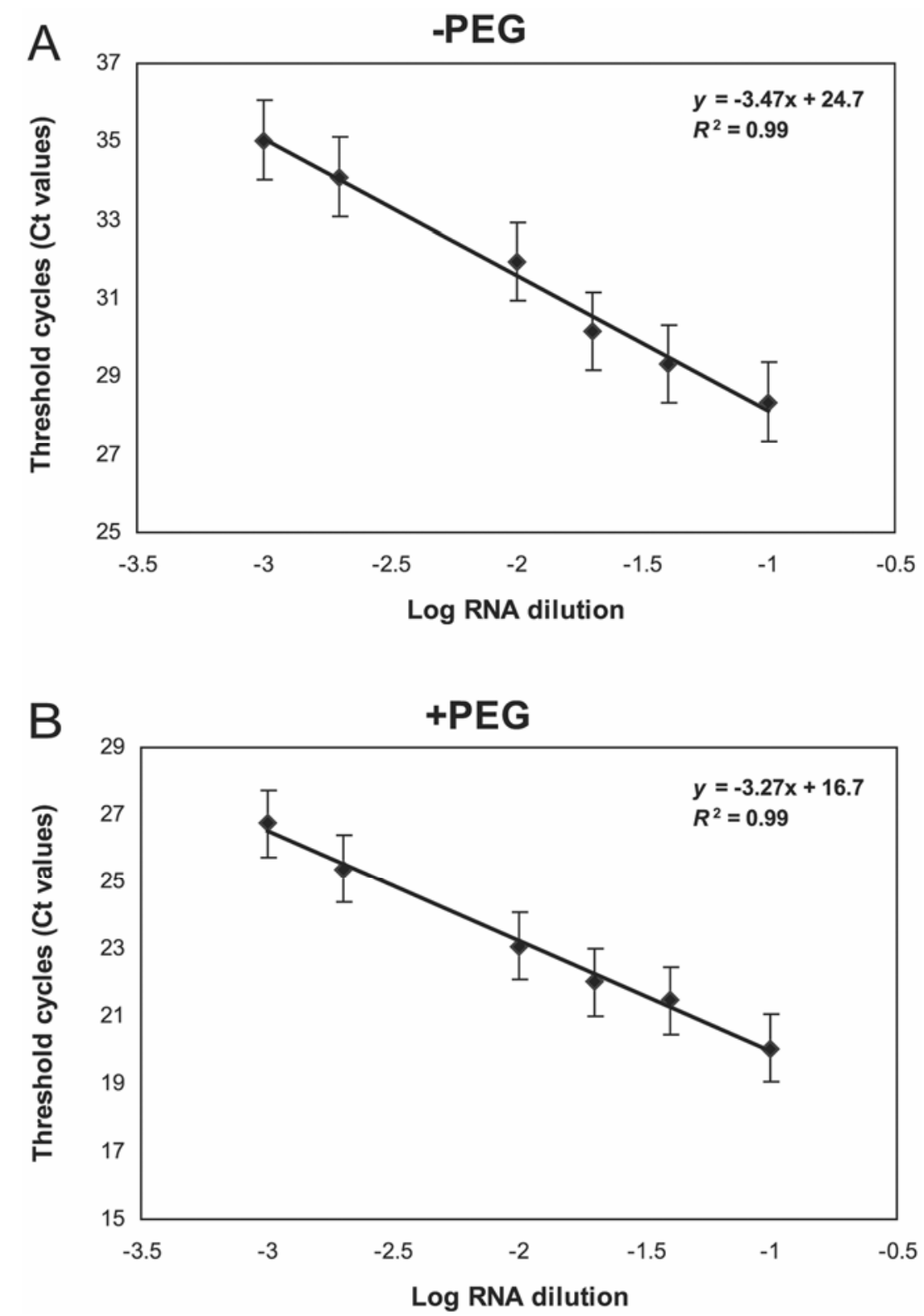

Fig. 2. Standard curve of cycle threshold $(\mathrm{Ct})$ values calculated from serial dilutions of RNA from Tomato ring spot virus-infected grapevine leaf tissue with standard error bars indicated. A, RNA was extracted without the addition of polyethylene glycol (PEG). B, RNA was extracted with the addition of polyethylene glycol. Differences among the slopes of the regression lines for each treatments were statistically significant $(\alpha=0.05)$. fold dilutions were not equal to one cycle increase as expected, and the 1:13 dilution of the ToRSV1f/1r crossed the cycle threshold later than subsequent dilutions, indicating PCR inhibition. Because the primer pair ToRSV1f/1r generated stronger primer dimer products than ToRSV2f/2r, primer pair ToRSV2f/2r was used for the subsequent detection of ToRSV in host tissues.

Real-time PCR detection of ToRSV in host tissues. The primer pair ToRSV2f/2r detected ToRSV from replicate samples of Vidal Blanc leaves, stems, and buds from commercial vineyards and greenhousegrown grapevines. These same primers detected ToRSV from four different grapevines of symptomatic DeChanauc growing in a commercial vineyard and from two $C$. quinoa plants inoculated with a strain of ToRSV from apple (Table 1). Symptomatic DeChanauc apparently contains ToRSV in greater quantities (lower $\mathrm{Ct}$ values) than Vidal Blanc and C. quinoa (Table 1). No ToRSV was detected in the nine cultivars that were grown from four bud cuttings heat treated at $50^{\circ} \mathrm{C}$ for $30 \mathrm{~min}$ prior to rooting (Table 1).

Comparison of ELISA and real-time PCR detection. In 2004, ELISA tests from leaves of 6-month-old cuttings from a naturally infected vineyard were negative for ToRSV. ELISA test results from roots of the same 6-month-old cuttings yielded several positive plants; $1,3,5,7,8$, and 11 (Table 2). Root sampling for ELISA was destructive, and cutting 1 died before it could be sampled using real-time RT-PCR (Table 2). In 2004, real-time RT-PCR test results using the primer pair $2 \mathrm{f} / 2 \mathrm{r}$ from leaves yielded six positive plants; $3,5,7$, 8, 11, and 16. In 2005, subsequent ELISA and real-time RT-PCR testing of leaves verified the results obtained in 2004, because cutting 16 was both ELISA and realtime RT-PCR positive.

RNA extraction and PCR efficiency. The concentration of RNA obtained using the RNeasy extraction kit with and without PEG was 8.4 and $4.4 \mathrm{ng} / \mu \mathrm{l}$, respectively. PCR efficiency was determined to be 1.94 $\left(y=-3.47 x+24.7, R^{2}=0.99\right)$ when utilizing the primer pair ToRSV2f/2r and RNA extracted using the RNeasy extraction kit without PEG (Fig. 2A). PCR efficiency was $2.02\left(y=-3.27 x+16.7, R^{2}=0.99\right)$ when utilizing the primer pair ToRSV2f/2r and RNA extracted using the RNeasy extraction kit with PEG (Fig. 2B). The $\mathrm{Ct}$ values for all dilutions obtained from the RNeasy extraction without PEG were higher than those recorded for identical dilutions for the extraction with PEG (Fig. $2 \mathrm{~A}$ and $\mathrm{B}$ ).

Genetic variation. Phylogenetic analysis of sequenced positive PCR products showed that Pennsylvania strains of ToRSV (PSU1 and ToRSV5) were divergent from raspberry and peach isolates, but not as divergent as GYV from the Pacific 
Northwest (Fig. 3). Of 316 characters, 228 were constant and 40 variable characters were uninformative, with 48 parsimonyinformative characters; $\mathrm{CI}=0.857, \mathrm{RI}=$ $0.721, \mathrm{HI}=0.143$.

\section{DISCUSSION}

Primers from conventional RT-PCR and IC-PCR methods for the detection of ToRSV $(9,13)$ were not adaptable to the real-time RT-PCR SYBR Green detection of ToRSV; therefore, two primer pairs were designed and evaluated in this study. Although both primer pairs amplified ToRSV, the primer pair ToRSV2f/2r (330 bp) was more efficient throughout this study. The primer-dimer for the 330-bp product was minimal, occurring after 36 cycles, and easily distinguished from the true product using the Cepheid Smart Cycler melt curve analysis program. The RTPCR product from ToRSV1f/1r primer pair yielded a 130-bp product, but amplification curves did not cross the $\mathrm{Ct}$ until later in the amplification cycle. The primer pair ToRSV2f/2r successfully detected ToRSV from multiple samples of two grape cultivars and from $C$. quinoa, which is not genetically related to grape. The primer pair did not detect ToRSV in asymptomatic grapevine. Both primer pairs failed to amplify an isolate of PRMV, a nontarget nepovirus. Blast searches using ToRSV2f/ $2 \mathrm{r}$ show that they will successfully amplify GYV.

Based on a comparison of test results between ELISA and real-time RT-PCR over a 2-year period from greenhousegrown vines, RNA extraction using only the RNeasy kit from Qiagen (without the addition of PEG) was sufficient for the detection of ToRSV and more sensitive than ELISA based on limited sampling. Real-time RT-PCR detected all ELISApositive samples, but ELISA failed to detect all real-time RT-PCR-positive samples in 2004 (Table 2). ELISA failed to detect ToRSV in leaves of 6-month-old rooted cuttings, whereas real-time RT-PCR detected the virus in leaf tissue. In 2005, ELISA detected ToRSV from sample 16, suggesting that the RT-PCR positive in 2004 was not a false positive.

The addition of PEG increased PCR efficiency (2.02), by eliminating proteins (14). The inclusion of PEG in the RNA extraction resulted in the expected onecycle increase between the twofold dilutions (1:25 and 1:50). Based on these observations, it is recommended that PEG should be added to the RNeasy extraction protocol and that $11.75 \mu$ of $1: 25$ dilution of template RNA can be used in a standardized SYBR Green assay for detecting ToRSV. However, the data in this study indicate that dilutions from 1:10 through 1:1000 were effective.

Until multiple isolates of ToRSV from grape have been fully characterized following the methods outlined by Wang and
Sanfaçon (18), natural variations in ToRSV populations could lead to false negatives if specific probe-based PCR methods, such as TaqMan, are implemented based on the coat protein gene region. The primer pairs in this study were designed based on regions of the coat protein gene that were conserved for the primer sequences, but the coat protein gene sequence between the forward and reverse primers was variable between isolates. Developing a single TaqMan probe that could detect all strains based on the 330-bp region amplified by the primer pair $2 \mathrm{f} / 2 \mathrm{r}$ is unlikely. The primer pair designed by Griesbach (7) in the more conserved polymerase gene region could be exploited for future development of a Taqman-based assay; however, more isolates of virus from grape need to be sequenced and strain variation determined. The Pennsylvania ToRSV isolates (PSU1 and ToRSV5) diverge from ToRSV from peach by 60 and 56 nucleotides. ToRSV isolates PSU1 and ToRSV 5 are separated by 32 nucleotides. Further evidence is needed to determine whether they are or are not different strains.

Wang and Sanfaçon (18) showed that direct-sequenced PCR products could be

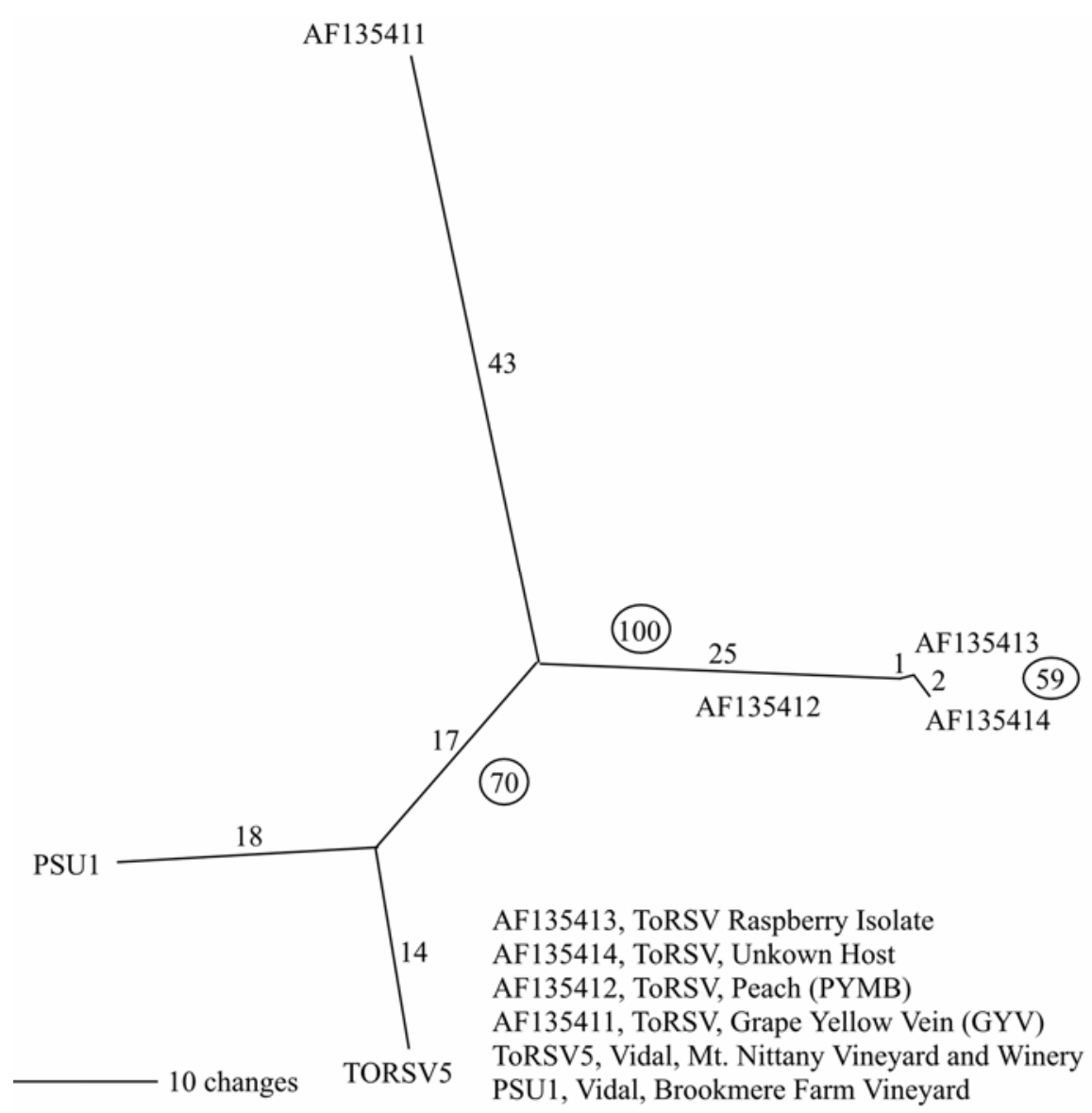

Fig. 3. Parsimony analysis of 330-bp sequence region of Tomato ring spot virus coat protein gene. Phylogram of single most parsimonious tree: 119 steps; 0.857 , consistency index; 0.721 , retention index; 0.143 , homoplasy index; branch lengths are indicated by the numbers above the branches; and bootstrap values are indicated by the numbers in circles $(500$ replicates with 500 random addition replications). sequence data obtained in this study were obtained directly from the RT-PCR products. The cycle sequence data showed that vines maintained in the greenhouse and grape tissue tested from commercial vineyards were infected with a previously unreported ToRSV strain from the northeastern United States. The method presented here can be used for the detection and initial phylogenetic characterization of ToRSV isolated from grape and other hosts. Pham et al. (13) was able to differentiate strains of the Newcastle virus using melt curve analysis, eliminating the need to sequence real-time RT-PCR products. When strain variation is more thoroughly documented for ToRSV, it may be possible to differentiate strains following the methods of Pham et al. (13) using the primers designed in this study.

This study establishes a rapid one-step real-time RT-PCR SYBR Green assay for ToRSV detection in grapevines and also provides initial evidence of a divergent strain of ToRSV from grape in Pennsylvania. The detection method described here may be useful to virologists and diagnosticians involved in developing clean grapevine stock for the industry. used to make phylogenetic inferences. The 


\section{ACKNOWLEDGMENTS}

This research was supported in part by agricultural research funds administered by the Pennsylvania Department of Agriculture (ME\# 443256) and the Pennsylvania Wine Marketing and Research Board (ME\# 443448, ME\# 444468). The Viticulture Consortium East provided grant funds in support of the vineyard survey, which served as the foundation for this report. We thank Dr. Ruth Welliver, Pennsylvania Department of Agriculture for providing the ToRSV infected Chenopodium quinoa plants and Dr. Wakar Uddin for his assistance in calculating the standard curves.

\section{LITERATURE CITED}

1. Bitterlin, M. W., and Gonsalves, D. 1988. Serological groupings of tomato ringspot virus isolates: implications for diagnosis and crossprotection. Phytopathology 78:275-285.

2. Burr, T. J., Ophel, K., Katz, B. H., and Kerr, A. 1989. Effect of hot water treatment on systemic Agrobacterium tumefaciens biovar 3 in dormant grape cuttings. Plant Dis. 73:242-245.

3. Bustin, S. A., and Nolan, T. 2004. Pitfalls of quantitative real-time reverse transcription polymerase chain reaction. J. Biomol. Technol. 15:155-166.

4. Clark, K., Sergeeva, V., Emmett, R. W., and Nair, N. G. 2004. Survival of Phomopsis viticola in grapevine cuttings after hot water treatment. Aust. Plant Pathol. 33:317-319.
5. Crow, E. L., Davis, F. A., and Maxfield, M. W. 1960. Statistics Manual. Dover Publications, Inc., New York.

6. Gooding, G. V. 1963. Purification and serology of a virus associated with the grape yellowvein disease. Phytopathology 53:475-480.

7. Griesbach, J. J. 1995. Detection of tomato ringspot virus by polymerase chain reaction. Plant Dis. 79:1054-1056.

8. Mackay, I., Arden, K., and Nitsche, A. 2002. Real-time PCR in virology. Nucleic Acids Res. 30:1292-1305.

9. Maliogka, V. I. 2006. Molecular identification, reverse transcription-polymerase chain reaction detection, host reactions, and specific cytopathology of Artichoke yellow ringspot virus infecting onion crops. Phytopathology 96:622629.

10. Martin, R. R., Eastwel, K. C., Wagner, A., Lamprecht, S., and Tzanetakis, I. E. 2005. Survey for Viruses of Grapevine in Oregon and Washington. Plant Dis. 89:763-766.

11. Mountain, W. L., Powell, C. A., Forer, L. B., and Stouffer, R. F. 1983. Transmission of tomato ringspot virus from dandelion via seed and dagger nematodes. Plant Dis. 67:867868.

12. Pearson, R. C., and Goheen, A. C. 1988. Compendium of Grape Diseases. The American Phytopathological Society Press, St. Paul, MN.

13. Pham, H. M., Konnai, S., Usui, T., Chang, K.
S., Murata, S., Mase, M., Ohashi, K., and Onuma, M. 2005. Rapid detection and differentiation of Newcastle disease virus by realtime PCR with melting-curve analysis. Arch. Virol. 150:2429-2438.

14. Rowhani, A., Biardi, L., Routh, G., Daubert, S D., and Golina, D. A. 1998. Development of a sensitive colorimetric-PCR assay for detection of viruses in woody plants. Plant Dis. 82:880884.

15. Stace-Smith, R. 1984. Tomato ringspot virus In: CMI/AAB Descriptions of Plant Viruses, no. 290. Commonwealth Mycological Institute/Association of Applied Biologists, Kew Surrey, England.

16. Stewart, E. L., and Wenner, N. G. 2004 Grapevine decline in Pennsylvania and New York. Wine East, July-August, 32:12-21, 51.

17. Tattersall, E. A. R., Ergul, A., Alkayal, F., DeLuc, L., Cushman, J. C., and Cramer, G. R. 2005. Comparison of methods for isolating high-quality RNA from leaves of grapevine. Am. J. Enol. Vitic. 56:400-406.

18. Wang, A., and Sanfaçon, H. 2000. Diversity in the coding regions for the coat protein, VPg, protease, and putative RNA-dependent RNA polymerase among tomato ringspot nepovirus isolates. Can. J. Plant Pathol. 22:145-149.

19. Wong, M. L., and Medrano, J. F. 2005. Realtime PCR for mRNA quantitation. BioTechniques 39:75-85. 